\title{
Modeling the Smartphone Game to Improve Players' Focus Case Study of Game Dumb Ways to Die
}

\author{
Elisa Purnamasari, Ridwan Sanjaya \\ Department of Information Systems, Soegijapranata Catholic University \\ Joe_elz@ymail.com
}

\begin{abstract}
Commonly, playing a game is judged as an activity which spend a lot of time, money, and energy. Players usually spend their money to buy vouchers to play and also buy characters, weapons and equipments which provided in the game. Players who addicted to game mostly spend their time and energy to satisfy their desire to solve the challenge on a game.
\end{abstract}

However, not all of games give the negative impacts. There are a lot of advantages which can be obtained by games, such as to train our memory, precision, speed, and even ability to get money from games. A game called "Dumb Ways to Die" that can be found on smartphone is an example of game to increase speed and concentration of people who play it.

There are a need to find some characteristics of a game which has positive effects for the players. Those characteristics can be formulated as the example of a good game. This paper will analyze the opinion and produce the conclusion from a survey of playing "Dumb Ways to Die" to generate a positive game model.

Keywords- positive game, speed, concentration, favorable, game model

\section{INTRODUCTION}

Nowadays, smartphone is not only being a need, but it has changed to be a trend and lifestyle [3]. Even though smartphone is only a device in daily activity, it has a lot of influences in human life [5]. Sophistication which can be found on smartphone makes the users of smartphone are able to do many things such as chatting, browsing, playing games, writing, and e-banking [5].

The presence of smartphones has increased the number of games, especially kids games. But, sometimes it is considered to be something negative for several people because it wastes the time, money, and energy [2], even though not all game produce those negative impacts. There are many things we can get from a lot of games that exist [2], one of the benefit it is to get money.

\section{LITERATURE REVIEW}

Dumb Ways to Die is the one of application from various games which already exist that connecting many elements such as :

\subsection{Concentration}

Concentration is focusing his/her attention to his/her work or activity [1]. Concentration that applied in this game can be seen on several challenges that can be found on this game such as:

a. The way how to keep the duck safe and not bitten by the bear.

b. The way how to keep the egg's balances.

c. The way how to choose a panda behind the door among two psycho characters.

d. The way how to take the toast inside the roaster without shocked by the electricity.

e. The way how to add the mustard to the hotdog in order to fit it with the dotted line, so the character is not bitten by the snake.

\section{$2.2 \quad$ Speed}

Speed is somebody's ability to do a continuous movement on the same type with the shortest time. [4].

There are several applications of speed that exist on this game:

a. The way how to blow away a plane in order to avoid the plane fell to the ground. 
b. The way how to clean up the screen from the vomit that created by the character of the game.

c. The way how to defense the character from the piranha to avoid getting bit by the piranha.

d. The way how the character banishes the bees from its face.

e. The way how to run as quick as possible to avoid the character burnt.

f. The way how to merge the balloons to its rope, so the character does not need walk into the rail and getting hit.

g. The way how to seal the holes to avoid the character are running out of the blood.

h. The way how to move the character as quick as possible from the yellow line so it does not struck by the train.

i. The way how to arrange the word "patience" as quick as possible in order to avoid the character are not getting hit by the train when it crosses the rail.

\section{RESEARCH METHODOLOGY}

To prove that "Dumb Ways to Die" game can increases concentration and speed, a research was held with 20 people as the subjects, (student and college student) to play that game 15 minutes a day for 5 days consecutively.

Table 1. High Score Table In Dumb Ways to Die Game

\begin{tabular}{|c|c|c|c|c|c|}
\hline \multirow{2}{*}{ Player } & \multicolumn{5}{|c|}{ Day } \\
\cline { 2 - 6 } & 1 & 2 & 3 & 4 & 5 \\
\hline A & 1328 & 1038 & 1483 & 1549 & 1884 \\
\hline B & 950 & 1250 & 532 & 1023 & 1365 \\
\hline C & 1003 & 2399 & 2540 & 2625 & 3334 \\
\hline D & 1546 & 1640 & 1450 & 1650 & 1550 \\
\hline E & 3205 & 1325 & 1500 & 2000 & 2080 \\
\hline F & 1550 & 1341 & 1948 & 1548 & 1874 \\
\hline G & 2004 & 2272 & 922 & 1632 & 3132 \\
\hline H & 1972 & 2050 & 1943 & 2945 & 5393 \\
\hline I & 1320 & 1560 & 1795 & 1958 & 2032 \\
\hline J & 340 & 669 & 1712 & 1355 & 1388 \\
\hline
\end{tabular}

\begin{tabular}{|c|c|c|c|c|c|}
\hline \multirow{2}{*}{ Player } & \multicolumn{5}{|c|}{ Day } \\
\cline { 2 - 6 } & 1 & 2 & 3 & 4 & 5 \\
\hline K & 1645 & 1236 & 1481 & 1755 & 1892 \\
\hline L & 1470 & 1550 & 2213 & 1744 & 1689 \\
\hline M & 767 & 1261 & 1077 & 1041 & 1161 \\
\hline N & 920 & 1109 & 1382 & 1575 & 1928 \\
\hline O & 1036 & 1584 & 1634 & 1897 & 2089 \\
\hline P & 1121 & 1025 & 1445 & 1536 & 1447 \\
\hline Q & 1541 & 1330 & 1426 & 1723 & 2193 \\
\hline R & 1405 & 1195 & 1101 & 1461 & 2095 \\
\hline S & 799 & 899 & 1355 & 1582 & 1897 \\
\hline T & 1667 & 1987 & 2651 & 1634 & 1679 \\
\hline
\end{tabular}

Source: Primary data processed, 2014

\section{RESULTS AND DISCUSION}

Based on the research that was held on 20 people, obviously the concentration level, speed, and the accuracy from each player in average has increased day by day, it can be seen from the score that getting higher. According to the survey, there are a lot of superiorities that contains in this game [6] such as:

1. $20 \%$ people assume that "Dumb Ways to Die" game is interesting, attractive and innovative.

2. $25 \%$ people assume that "Dumb Ways to Die" game is pushes the player to keep focus, sharp, to train agility and memory.

3. $35 \%$ people assume that "Dumb Ways to Die" game does not makes bored because it use so many interaction models (tap, swipe, drag, etc).

4. $20 \%$ people assume that "Dumb Ways to Die" game is utilizing feature that contains in the device like touch screen (tap, swipe, drag, pinch), gryscope (device tilt), microphone device (blow).

In this game, player not only forced to totally concentrate utilize a split second to avoid danger that threaten his or her life, but also increasing the speed of player's hand when touching screen of their cell phone, 
because when the challenge changed, time that needed to finish it are shorter there are 3 chances that gives for player to complete 15 challenges to survive in this game before the game is over.

According to the interview that was held to 20 respondents, there are 3 challenges on this game which have an effect on daily life.

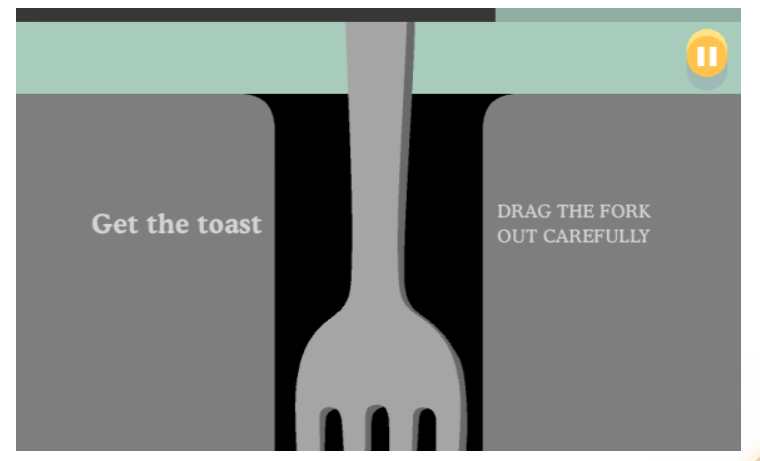

Fig. 1 Train Concentration

Through this challenge, $10 \%$ respondents are going to be more careful and predict all the possibilities that exist with ambient conditions especially when they want to go before the vehicle in front of them when they are driving, not only that, the type of game like this even applied as concentration test by Sundial Puspa Iptek Bandung for interactive learning.

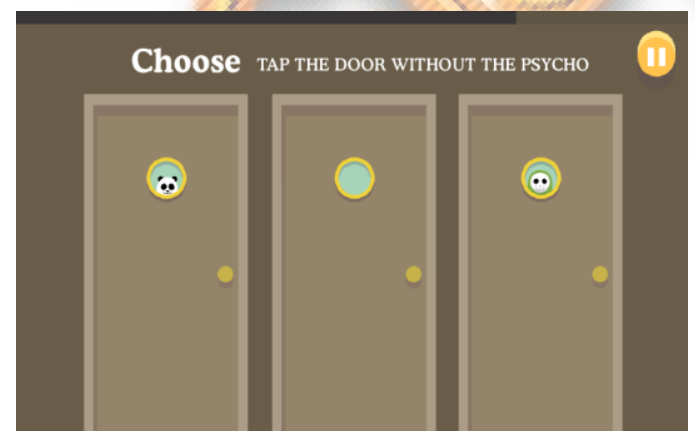

Fig. 2 train concentration and accuracy

Through this challenge, $10 \%$ respondents are going to be more thoroughly to do a math question about counts a sequence number. On this game, respondents are not only trained being thoroughly but also to think quickly and accurate so they are going to be accustomed when they are facing the similar challenge.

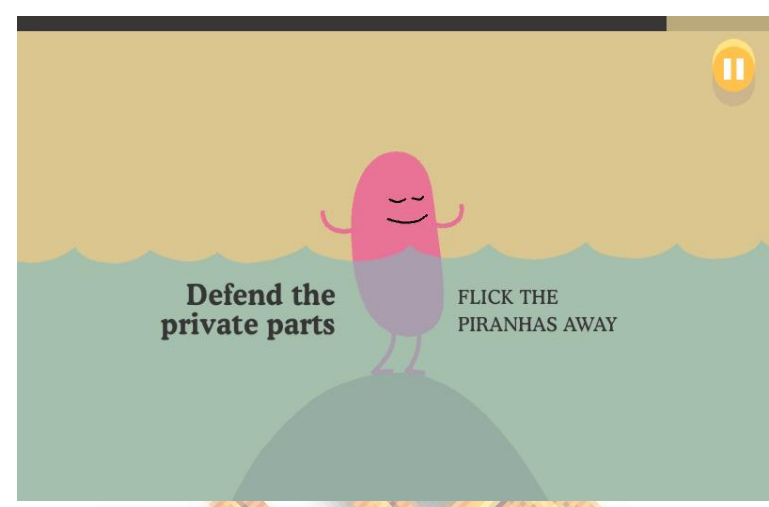

Fig. 3 Train Agility and Awareness

Through this challenge, $10 \%$ respondents are going to be more aware when they are crossing the street. This challenge told us to be more aware thus we do not know what kind of dangers in front of us and when it are going to happen.

\section{CONCLUSIONS}

Based on the result of research and discussion about "Dumb Ways to Die" game, can be conclude that $25 \%$ of games have a positive effect for the player, one of it is increasing player's concentration. From 20 people who have already play that game, among $35 \%$ of them said that the characteristic of a good game is has a positive effect which can be applied on the daily life just like cross the road, doing a counts on math question, and go before a vehicle in front of them, beside of that, the game can be a way for interactive learning too. On the game we are tend to be forced to take a decision quickly and accurately to complete a mission. Playing game is also a good way exercises our brain to avoid get easily senile. Indirectly, game makes our brain takes a decision quickly and accurately in the real world. 


\section{ACKNOWLEDGMENT}

The authors gratefully acknowledge to scholarship Beasiswa Unggulan support from Bureau for Planning and International Cooperation, Ministry of Education and Culture of Indonesia.

\section{REFERENCES}

[1] Abu Daud, Pengertian dan Ciri-ciri Konsentrasi Belajar, Senin, 22 November 2010, 20 April 2014 (diakses), media internet, abudaud2010.blogspot.com/2010/11/peng ertian-dan-ciri-ciri-konsentrasi.html

[2] Alwi, Video Game Bisa Selamatkan Dunia, 20 Maret 2010, 25 April 2014 (diakses), internet, http://m-alwi.com/manfaatbermain-game.html

[3] Citizen6, Smartphone yang Semakin Tenar, 24 Oktober 2013, 25 April 2014 (diakses), internet, http://news.liputan6.com/read/728554/sma rtphone-yang-semakin-tenar

[4] Dj Blackersz, Artikel Penjas, Definisi Kecepatan, 10 November 2011, [Accessed on 19 April 2014], media internet, http://pojokdefinisi.blogspot.com/2011/11/ definisi-kecepatan.html?m=1

[5] Latifaa, Dampak Positif dan Negatif dari Komputasi Modern, 14 Maret 2014, [Accessed on 25 April 2014], internet, http://tetehtifa.blogspot.com/2014/03/dam pak-positif-dan-negatif-dari.html

[6] Sigit Purnomo, [Activity 2] Model Interaksi pada Game Dumb Ways to Die, Oktober 2013, [Accessed on 25 April 2014], internet, http://sigitpurnomo.com/forum/discussion/ 81/activity-2-model-interaksi-pada-gamedumb-way-to-die/p1 